21 Introduction

3 Forest management, and more specifically sustainable forest management, is no simple task

4 since forests are complex ecosystems and their management relates to manifold societal

5 needs. Because of this, several authors (e.g. Allen and Gould, 1986; Lachapelle et al., 2003;

6 Carroll et al., 2007; Duckett et al., 2016) classify forest management as a wicked problem.

7 The concept of wicked problem refers to unconventional and complex problems, which are

8 difficult or impossible to solve because of incomplete, contradictory, and changing requirements that are often difficult to recognise (Rittel and Webber, 1973). Likewise, the successful implementation of sustainable forest management is often disputable, and requires intensive and continuous dialogue and cooperation between the interested parts, which might include landowners, natural and social scientists, policy makers and citizens (Buizer et al., 2011). Since wicked problems are complex and intertwined, defining and understanding them requires collaboration between scientists and practitioners, and consequently participatory research approaches.

Fortmann \& Ballard (2011) considered that collaboration between conventional scientists and non-experts produces more accurate and policy relevant knowledge than the collaboration of conventional scientists without the inclusion of people with an interest or those affected by the policies at stake (stakeholders). The inclusion of "lay persons" or interested citizens is usually motivated by three possible types of arguments, namely, the democratic right of citizens to be included in decision processes, better effectiveness in the design of solutions, and better outcomes (normative, instrumental or substantive rationale) (Stirling, 2006; Scherhaufer, 2014). Transdisciplinary and interdisciplinary approaches have gained considerable attention over the past few decades with the development of sustainability science (Jantsch, 1972; Schophaus et al. 2004; Hirsch Hadorn et al. 2006; Lang et al. 2012; Ruppert-Winkel et al., 2015). Transdisciplinarity is a process of collaboration between academics and non-academics on specific real-world problems (Walter et al., 2007). Interdisciplinarity integrates perspectives, information, data, techniques, tools, concepts, and/or theories from two or more disciplines (Cronin, 2008). Inter- and 
(e.g., Weingart and Stehr, 2000; Gibbons and Novotny, 2001; Maasen et al., 2006) and on methods and principles to ensure successful implementation (e.g., Schophaus et al., 2004; Bergmann et al., 2005). Institutional settings predefine which actors, research questions, methods and types of results can be included in the research, and through this provide important limitations for project management (Weiss et al. 2011). There are also advantages to investigating land use and management issues in geographically distinct areas as it allows for the examination of a wider variety of behaviours and their cultural meaning, which in turn improves the probability that their meaning is related to the performance of the behaviour itself rather than local historical identities (Burton et al., 2008).

A fundamental issue of sustainable forest management is land ownership, which relates directly to the management of forests and the provision of forest ecosystem services (Weiss et al., this issue). In Europe, around $60 \%$ of forests are owned by several million private owners (EU, 2013) and private forest ownership is still increasing, due to restitution processes in Eastern European countries, community buy-outs in Western Europe (e.g. United Kingdom), and afforestation of agricultural land (e.g. Portugal) (Zivojinovic et al., 2015). The European Union (EU) has no common forest policy, but it promotes sustainable forest management since the late 1990s in its forest strategies (e.g. European Forest Strategy). However, measures affecting the use of forests are under the responsibility of individual Member States and therefore covered by national sectoral policies (Winkel et al., 2013).

Forest owners also have their own objectives, which may not align with European, national and local policy objectives. Wallace et al. (2016) consider that inadequate knowledge of forest owners' values may severely undermine the effectiveness of natural resource management strategies, including sustainable forest management. In order to design a policy framework that effectively converts policy objectives into practice, European and country-level policy-makers need to understand forest owners' behaviours, attitudes and motivations towards forest ownership and management as these are very diverse and changeable (Weiss et al., 2017). Researchers have the important role of deciphering local contexts and communicating their findings with decision makers (Brown and Everard, 2015) so that policies can be better designed and implemented. While there is a growing body of 
research on landowners' behaviours and attitudes towards policy, there is still a need to understand the challenge of sustainable forest management from a transdisciplinary perspective and to understand how it varies across countries. This matter was explored by COST Action FP1201 - Forest Land Ownership Change in Europe: Significance for Management and Policy" (FACESMAP) ${ }^{1}$.

In Europe, the longest-running framework supporting trans-national cooperation among researchers and stakeholders is COST - European Cooperation in Science and Technology ${ }^{2}$. Actions funded by COST allow European researchers to develop their own ideas in any science and technology field in collaboration with stakeholders over a period of 4 years. The aim of COST is to close the gap between science, policy and society throughout Europe and beyond by taking advantage of advanced multidisciplinary research. COST Actions support pan-European networking of nationally funded research activities through the financing of conferences, meetings, training schools, short scientific exchanges or other networking activities around specified topics. The specific nature of COST Actions lies in the bottom-up principle that allows any researcher interested to join the network and undertake collaborative research activities on a voluntary and unpaid basis. Main outputs are usually joint state-of-art reports, joint review articles, joint comparative analyses and other joint publications. COST Actions typically include an extensive network of scientists from all across Europe and from a wide background of disciplines (e.g. agronomy, ecology, forestry, hydrology, geography, geology, soil science, sociology, human geographers, and economists) and research approaches (e.g. interdisciplinary, transdisciplinary). The Actions under the theme "Forests, their Products and Services" usually involve bi-annual meetings of scientists in different European countries, which also include trips to the field. This constitutes an excellent opportunity for collaboration, engagement and integration of knowledge between scientists and regional and local stakeholders.

The COST Action FP1201 - FACESMAP, carried out between 2013 and 2016, aimed to analyse forest ownership changes in Europe and their significance to management and policy. Around 70 researchers from about 25 European countries participated in the activities

\footnotetext{
${ }^{1}$ http://www.cost.eu/COST_Actions/fps/FP1201

2 http://www.cost.eu/COST Actions
} 
established by FACESMAP. In order to ensure an effective collaboration between FACESMAP participants and regional and local stakeholders, i.e., those with an interest in the problem being studied and/or who might be impacted by a potential policy change resulting from the research findings, an inter- and transdisciplinary approach named Travellab was specifically developed within this COST Action.

The Travellab aimed to replace casual field trips with more structured stakeholder engagement activities based upon the topics covered by FACESMAP, with the objective of enhancing joint learning and triggering formulation of relevant research questions for policy and practice, and thus better utilising the field visits embedded in the framework of the COST Action FACESMAP. The management of the Action allocated specific time to develop the whole methodology in order to ensure improved learning while meeting and visiting field sites in different European countries. This is an add-on when compared to traditional COST Actions in the field of "Forests, their Products and Services", and possibly to other Actions in other fields. This basic concept of "learning while travelling", which originated the name of the approach as Travellab, can be adapted to similar scientific networks or research projects where field visits are embedded in the project meetings agendas. Effective communication and stakeholder engagement have a central role in knowledge production and exchange and this suggests the adoption of participatory research methods based on the social learning theory and on action research (Black 2000; Scherhaufer 2014; Schauppenlehner-Kloyber and Penker 2015; Fleming and Vanclay 2010).

International projects in the fields of forestry or land management often foresee regular project meetings, fieldtrips and stakeholder discussions in order to build a strong and effective collaborative group with a common understanding of the research problems and project goals. However, these projects usually fail to address the statements included in the project proposals and do not allocate time and resources to develop joint learning methods, including all project participants, with a specific research focus (Zscheischler and Rogga, 2015). The COST Action FACESMAP addressed this gap by establishing the Travellab with the specific objective of developing joint learning processes for improved learning, which can be replicated in future projects on sustainable land management. In addition, the Travellab also aimed at assessing the effectiveness of joint learning in its implementation. 
Insights from action research guided the development of the Travellab, in which scientists "engage with participants in a collaborative process of critical inquiry into problems of social practice in a learning context" (Argyris et al., 1985). The Travellab is therefore a collaborative, iterative and reflective approach that includes the joint development of learning methods, systematic joint reflection, and constant readjustment of the approach based on this reflection, and throughout the time of the Action.

This article aims to describe the development of the Travellab so this can guide others in the implementation of similar projects in the future on how to apply the approach successfully in order to stimulate joint learning about forest ownership and management issues in Europe. In addition, this article also aims to assess the value added by the Travellab in regards to improve joint learning. Therefore, section 2 describes the development of the Travellab and the concepts that inspired the approach, including the choice of participatory research methods. Section 3 presents the methods and materials used to assess the strengths and limitations of the approach. Section 4 presents the results of the reflection and evaluation of the Travellab and more specifically the value added by the Travellab to improve joint learning, and presents the current limitations of the approach. Section 5 discusses the results in relation to the assessment of the effectiveness of the Travellab, and Section 6 provides recommendations for future implementation. This article does not undertake an in-depth analysis of the knowledge and information obtained during the implementation of the Travellab as this is the object of another article.

\section{Development of the Travellab}

\subsection{Conceptual approach}

There is increasing demand from several research councils (e.g. H2020, Swedish Research Council Formas, United Kingdom Research Councils), development funders (e.g. DFID ${ }^{3}$, SIDA $^{4}$, World Bank) and Government agencies for effective stakeholder interaction which

\footnotetext{
${ }^{3}$ https://www.gov.uk/government/organisations/department-for-international-development/about/recruitment

4 https://www.sida.se/English/
} 
may require their inclusion as partners or advisors in research and development projects (Weiss et al., 2011; Slunge et al., 2017). Several authors (Armitage et al., 2008; Folke et al., 2005; Pahl-Wostl, 2007) consider that network governance and processes of social learning should be emphasised. Social learning, suggests that behaviour is learnt from the environment through the process of observational learning (Bandura, 1977). Its philosophy considers stakeholder participation and the integration of knowledge from different perspectives, and it involves critical thinking, interactions, dialogue, and questioning assumptions that underline individual concepts (Leeuwis et al., 2002). Social learning is a process of transformative social change in which participants critically question and potentially discard existing norms, values, institutions, and interests to pursue actions that are desirable to them (Keen et al., 2005). In natural resource management, social learning is gaining increasing attention as a fundamental process to coping with complexity and uncertainty (Lee 1993; Ison and Watson, 2007; Pahl-Wostl et al., 2009) and providing support to participation, collective action, and decision-making (Pretty 1995; Daniels and Walker 2001; Measham, 2009). Rodela (2012) considers that social learning advances the critique of the command-and-control approach to resource management and is generally regarded as an outcome of deliberative processes (Daniels and Walker, 1996) that go beyond the individual to include the social units and networks in which individuals interact (Reed et al., 2010).

To address these demands, and after considering that ordinary field trips embedded in the project meetings produce informal discussions but do not lead to deeper reflection, action and effective learning, the Steering Committee of COST Action FACESMAP suggested the development of the Travellab approach to strengthen stakeholder interaction in a systematic way. The objectives of establishing an approach to ensure effective stakeholder interaction for successful joint learning were to:

- Provide opportunities for the researchers to learn about regional issues affecting forest ownership and management;

- Assure that the research questions and information collected were relevant to policy and practice; 
- Feed existing scientific knowledge and results of the Action back to the relevant stakeholders;

- Enhance the effectiveness and impact of the Action.

The Travellab also aimed at assessing whether, and to what extent, learning is actually taking place. Several authors (Garmendia an Stagl, 2010; Reed et al., 2010; Cundill et al., 2012) consider that the way learning can be better facilitated is often not very clear, and measuring the learning and knowledge production that results from the interaction between researchers and stakeholders has been described as a critical gap in the literature (Schwilch et al., 2012). Inquiring more broadly into the nature of learning in a complex system is also promoted by action research approaches such as design-based research. This research methodology aims at improving educational practices through systematic, flexible, and iterative review, analysis, design, development, and implementation, based upon collaboration among researchers and practitioners in real-world settings (Wang and Hannafin, 2005).

201

Reed (2008) derived best practice guidelines for successful stakeholder involvement through reviewing the literature available on stakeholder participation in environmental management. This author recommends favouring stakeholder empowerment, equity, trust and learning as early as possible in the project. This allows the researchers to engage relevant stakeholders systematically throughout the process, to have clear objectives for stakeholder participation, to apply tailored methods, to involve skilled facilitators that help the group of people to understand the common objectives and to assist them to plan how to achieve these objectives, and to integrate both local and scientific knowledge.

By following an action research approach, the Travellab subsumes two main types of methods: the methods for quality stakeholder interaction and the methods to assess the effectiveness of joint learning due to the implementation of the Travellab. The wider range of participatory research methods available in the literature supplied the methods for Travellab and adapted to its own context and characteristics (Bryson, 2004; Wang and 
Travellab approach also took into consideration four factors that enhance group interaction

(Johnson and Johnson, 1987; Schauppenlehner-Kloyber and Penker, 2015). These are 1) the

fact that every single person has their own interests and needs; 2 ) the interaction and relational pattern between all participants; 3) the purpose of the interaction, and; 4) the physical, social and temporal environment in which the interaction takes place.

The literature on inter- and transdisciplinary research, social learning, action research and stakeholder participation informed, therefore, the design of the Travellab. Its main characteristics are similar to those attributed to design-based research by Wang and Hannafin (2005), namely: 1) Pragmatic; 2) Experiential; 3) Interactive, iterative and flexible; 4) Integrative; and 5) Contextual.

\subsection{Pragmatic}

The Travellab approach followed a pragmatic approach because its goals were to explore and solve real-world problems (The Design-Based Research Collective, 2003) through stakeholder interactions at the national, regional and local level. During the Travellab, specific topics were selected in each of the host countries (e.g. restitution in Eastern European countries, advisory services in Finland and Scotland), which were related to the main topics of the Action (forest ownership and management), and aimed to achieve indepth analysis and reflection. Open-ended questions were favoured to allow realistic stakeholder interaction. The practical dimensions of the Travellab, which also relate to its alignment with the COST Action framework, are as follows:

- COST Actions are open for all researchers in the participating countries interested in the topic; In the case of FACESMAP, 50-70 researchers from various social and natural science disciplines participated in the meetings;

- The participants had varying experience with qualitative research methods and participatory approaches;

- During the Action lifetime (2013-2016), one or two annual meetings are organised, preferably in different countries across Europe and depended on the interest and willingness of the participating researchers to contribute and to be the hosts; 
- Field trips embedded in the project meeting agendas and stakeholder interaction activities.

Usually, participants of forest-related Actions are very interested in visiting and experiencing local forests and meeting stakeholders, who themselves are usually willing to interact with visitors. The Travellab took advantage of the structure of conventional COST Actions to improve effective learning and to record systematically how effective learning occurred. It assumed the learning that arises through knowledge exchange between researchers with various disciplinary backgrounds (interdisciplinary), and between researchers and practitioners (transdisciplinary) is more effective and it is essential to solving real world problems.

\subsection{Experiential}

Fazey et al. (2005), for example, acknowledges the importance of experiential knowledge for effective environmental-related research and practice. The concept of the Travellab is the combination of the words 'travel' and 'lab'. The word "travel" represents the interaction between researchers and non-researchers (stakeholders) that occurred while travelling to the regions that include the cities of Sopron (Hungary), Solsona (Spain), Helsinki (Finland), Freiburg (Germany), Zagreb (Croatia), Krakow (Poland) and Inverness (Scotland), during the COST Action FACESMAP. The word 'lab' represents the fact that the field visits were undertaken in a living laboratory (i.e. the forest) where the researchers could experience the socio-environmental context of the sites visited, interact, and discuss with regional and local stakeholders. The researchers involved in the FACESMAP had various disciplinary backgrounds with research interests related to forest ownership research, forest policy, forest economics and forest management with a range of theoretical approaches ranging from sociology and political sciences to economics and management. A significant share but not the majority of the researchers had specific interest and experience in participatory research methods or qualitative methods of empirical social research. The Travellab, was 
The coordination of the Travellab was assigned to one Steering Group member (1st author of this article) with the support of a smaller group of FACESMAP participants (Travellab task group). The Travellab stimulated interaction with stakeholders in order to improve the researchers' understanding of the main themes of the three working groups (WGs) that constituted COST Action FACESMAP, namely, forest ownership types, motives and related changes (WG1), new forest management approaches (WG2), and the existing policies supporting forest owners and new management approaches (WG3). Stakeholders were selected through stakeholder analysis, which is the process of determining whose interests should be considered when developing and/or implementing research (Reed, 2008). Stakeholders were selected by local hosts of the meetings in consultation with the Travellab task group, in order to ensure that the stakeholders invited to participate in the Travellab were those most affected by changes in forest ownership, management, and policy and those with influence over the same factors at the local and national levels (after Freeman, 1984). The main questions asked to the stakeholders were formulated within the working groups of the Action on the day before the implementation of the Travellab (see appendix 1 for a non-exhaustive list of questions). The approach also encouraged spontaneous followup questions if time allowed.

Stakeholders varied in each host country, depending on the specific issues of each region visited. The main requirement included to meet traditional and non-traditional forest owners in each country. The following types of stakeholders participated in the Travellab between 2013 and 2016:

- Policy-makers - Members of governmental organisations that directly influence policy formulation;

- Advisory services - Representatives of non-government organisation (NGOs), forest owner associations (FOA), and consultant companies;

- State extension services - Representatives of the national and regional government forest services;

- Private forest owners - Individuals, families or private companies, including their interest organisations who own forests;

- Researchers - From universities and research institutes; 
- Community forests - Representatives of common/communal/community ownership forests;

- Contractors - Forest managers and anyone contracted by forest owners to undertake forest work.

Fifty-three stakeholders (including 20 forest owners) participated in the Travellab between 2013 and 2016. Of these, $27 \%$ were female and $73 \%$ were male. Figure 1 shows the stakeholders types involved in the Travellab.

[Figure 1 here]

\subsection{Interactive, iterative and flexible}

The Travellab consists of interactive collaboration between researchers and other stakeholders. It assumes that collaboration is required so interventions can trigger changes in the real world context (The Design-Based Research Collective, 2003; Wang \& Hannafin, 2005). The main principles of the Travellab were set in a collaborative two-day workshop in Solsona, Spain, in 2013. This collaborative workshop was steered by an expert in participatory research methods who trained a core group of FACESMAP participants, established as the Travellab task group, which included early career and established researchers. The main principle of the Travellab was to prioritise exchange of information between researchers and local stakeholders during field visits to forest sites, named as outdoor interactions with walking interviews (also employed by Bowditch et al., this issue), combined with subsequent stakeholder carousel workshops, named indoor interactions with flexible, semi-structured interviews. Note takers (at least six per working groups) wrote about the topics learnt and answers to the questions made (content notes), and about the effectiveness of the participatory research methods to improve the quality of the information exchanged and learning (observation notes). The main objective of having multiple note takers was to capture different dimensions of the same phenomenon, to enhance validity and reliability of the findings and to trigger individual reflection. Having multiple note takers also allowed the division of the large group of FACESMAP participants (always between 50 and 70 researchers) into smaller groups and parallel field visits in order 
to enhance the quality of the stakeholder interaction and of information captured during the interaction. After each Travellab session, researchers met within their working groups to reflect jointly on what was learnt and to summarise their main reflections. These working group summaries were presented in plenary for further discussion and reflection, favouring constant interaction among participants and joint development of the method. The reflections arising from the discussions were used to refine the Travellab method from one meeting to the next in order to ensure the comparability and continuity of the learning process. The individual observations and group reflections were, therefore, systematically recorded (in writing) in order to better understand how learning occurred. This iterative process happened successively until the end of the COST Action, and last Travellab (Inverness, Scotland in 2016).

The Travellab also comprised keynote presentations delivered by local experts before the outdoor interactions and the carousels who introduced the main forestry issues of the region and a booklet presented the forest owners, forest holdings, and other stakeholders was distributed to the researchers with the objective of facilitating the learning experience and triggering the reformulation of the pre-established questions. Two evaluation workshops, the first in Solsona in 2013 and the second in Inverness in 2016, were also held as part of the approach. The objectives of these workshops were to assess the effectiveness of the Travellab to improve joint learning and to collect recommendations for future implementations of the approach. The possibility of adjustment according to local characteristics and recommendations emerged from the evaluation workshop undertaken in Solsona in 2013 contributed further to the flexibility and interactivity of the approach. Figure 2 below illustrates the structure of the Travellab.

[Figure 2 here]

\subsection{Integrative}

The Travellab is integrative because it employs a variety of research methods and approaches. The integrative use of multiple methods in the research process results in data from multiple sources, which serves to confirm and enhance the credibility of findings 
(Wang \& Hannafin, 2005). The Travellab included on-site interactions with the forest owners (outdoor interaction) and an indoor interaction activity adapted from the "carousel" technique. During the indoor and outdoor activities, the whole group researchers in FACESMAP were divided into three smaller groups. During the carousel sessions, the three groups of researchers were allocated to three meeting rooms ('stations') with three different groups of stakeholders. Each 'station' had a facilitator and a fixed time to ask questions, discuss and take notes before moving to the next 'station'. Researchers entering a new 'station' were briefed about the questions that were asked during the previous session(s) in order to allow them to build their discussion upon previous contributions. The facilitation and interviewing roles were often taken by researchers with experience in participatory approaches, however early-career researchers were also encouraged to take on the role of facilitating the carousels and asking stakeholders questions. Qualitative data generated by the observation and content notes ensured the credibility of the results.

\subsection{Contextual}

Many researchers consider that the best way to understand a phenomenon is to view it in its context (Atieno, 2009). Therefore, the Travellab aimed to contribute to a better understanding of forest ownership and management issues across Europe by taking into account contextual differences between countries. The approach was implemented in regions surrounding the cities where the COST Action FACESMAP meetings took place, namely, Sopron (Hungary), Solsona (Spain), Helsinki (Finland), Freiburg (Germany), Zagreb (Croatia), Krakow (Poland) and Inverness (Scotland). The regions visited were selected in order to ensure diversity in terms of political (e.g. post socialist, Western governments), social (e.g. employment in forestry, forest ownership types), economic (e.g. importance of forest in Gross Domestic Product), institutional (e.g. share of private ownership) and geographical (Western, Eastern, Northern, Southern, Central European) characteristics.

Given the differences in national and regional contexts and topical foci, the Travellab was adapted to be appropriate to the setting of each region visited (e.g. selection of countryrelevant topics and stakeholders for in-depth discussion, introductory activities, location and order of field visits and stakeholder interaction meetings). The Travellab task group 
supported the hosts in the implementation of the Travellab approach in each country and the hosts suggested the stakeholders, field sites, facilities and dates. Subsequently, the background information provided to participants before each Travellab (e.g. introductory presentations, booklets) was adapted according to the local context and characteristics of the regions visited, and the pre-established questions were modified.

\section{Methods and materials to evaluate the effectiveness of the Travellab}

The Travellab approach aimed at encouraging joint learning through stakeholder interaction and it stimulated researchers' joint reflection to support the improvement and the implementation of the approach throughout the period (2013-2016) of the COST Action FACESMAP. In order to assess whether the Travellab was successful or not, its implementation was monitored through field observations and group reflections. These observations and reflections were recorded by designated note takers, and captured the answers to the questions asked during the discussions in the field and in the carousels (content notes), their observations about the implementation of the methods (observation notes), and their joint reflections about the effectiveness of each Travellab session within the working groups. The methods to assess the effectiveness of the Travellab are part of the methodological approach of the Travellab (as described in section 2.5). This assumes that researchers should keep detailed records during the design research process on whether the design outcomes (e.g. principles) have worked or not, how the approach has been improved, and what kind of changes have been made, as suggested by Wang \& Hannafin (2005).

In addition, two specific evaluation workshops were held with FACESMAP researchers who participated in the stakeholder engagement activities and joint reflections established by the Travellab (as mentioned in section 2.4). The first workshop was held in Solsona in 2013, and involved the whole group of FACESMAP participants (approximately 50-70 people), to discuss the question What did you learn with the Travellab? The workshop lasted 1.5 hours and was facilitated by one researcher with experience in participatory research methods. The second workshop was held in Inverness 2016 and consisted of three rotating sessions of 30 minutes each running in parallel, lasting a total of 1.5 hours. In this workshop, the whole 
group of FACESMAP participants was divided in three smaller groups of around 22 people to

442

443

444

445

446

447

448

449

450

451

452

453

454

455

456

457

458

459

460

461

462

463

464

465

466

467

468

469

470

471

472

discuss two main questions: How did the Travellab improve your understanding of forest ownership issues in Europe?, Which was the best Travellab session and why? And What would be your recommendations if we were to implement the Travellab again? The sessions were moderated and led by three researchers with experience in participatory research methods, who set the agenda and posed the initial question(s) to the workshop participants, and who ensured that ideas and experiences of all participants were captured successfully in writing (notes).

In order to investigate the effectiveness of the Travellab to improve learning a content analysis of the qualitative data recorded during individual observations and joint reflections within the working groups, stakeholder interaction, and the specific reflection workshops with researchers in Solsona and Inverness, was undertaken. Content analysis is a research method for studying documents, which might be texts of various formats, pictures, audio or video to explore patterns in communication in a replicable and systematic manner (Bryman, 2011). The content analysis aimed at answering the two main questions: 1) What did researchers learn from the Travellab? And 2) What was the added value of the Travellab to enhance researchers' learning and to trigger behaviour change in the real-world context? The qualitative data used in the analysis consisted of the compilation of the written notes classified as followed:

- Observation notes taken by designated researchers (three per working group per Travellab) allocated with the task of taking notes during the field visits and carousels in the seven regions visited. These notes narrate the stakeholder interaction dynamics, the strengths and shortcomings of the interaction methods and the researcher opinion about the effectiveness of the methods employed during the Travellab to improve learning;

- Content notes taken by designated researchers (three per working group, per Travellab), who recorded the answers to the questions asked during semi-structured, flexible, and often walking interviews to local stakeholders in the field sites and the carousels as well as the main topics discussed during stakeholder interactions; - Summaries of the joint reflections within working group on the topics learnt during the fieldtrips and carousels, and of the reflections on the effectiveness of the method, 
compiled by self-nominated working group representatives, and presented and discussed in the FACESMAP plenary sessions. These summaries provided information on how joint learning occurred and about the groups' views on the strengths and shortcomings of the Travellab, and recommendations for further refinement of the approach;

- Notes recorded during the specific reflection workshops (Solsona in 2013 and Inverness in 2016), which were set up to understand the views of the researchers involved in the Travellab about its effectiveness to improve their learning about forest ownership issues in Europe, and their suggestions for further refinement of the Travellab.

The whole set of written notes were compiled and entered into NVivo qualitative data analysis software (NVivo 10), and coded to reflect the main topics related to the effectiveness of the Travellab and also the main topics discussed in the field trips and carousels with local and regional stakeholders. Textual codes (keywords) were used to identify specific pieces of data corresponding to recurrent themes such as the main topics discussed during the interactions, the quality of the interaction with stakeholders, the quality of information exchanged during the interactions, or evidence that suggested that researchers were going to do something different as a result from their experience in the Travellab.

\section{The effectiveness of the Travellab}

\subsection{What did researchers learn, and what was the added value of the Travellab?}

Quotes taken directly from observation and content notes (see appendix 2) illustrate the main topics that emerged in the discussions with local stakeholders in the different regions visited. The main topics that researchers learnt about were: 
- Forest owners' perceptions of traditional forest owners and non-traditional (or new) forest owners;

- Knowledge systems used by traditional and/or old and new forest owners;

- Forest owners' perceptions on forest policy and the role of incentives;

- The needs of new forest owners;

- Gender perspectives;

- Old and new forest management approaches;

- Challenges (e.g. threats, risks) faced by forest owners.

More specifically, the analysis of the qualitative data showed that the Travellab ensured the quality of stakeholder interaction since it increased the amount and value of the information exchanged, the continuous flow of information between researchers and stakeholders, researchers' enjoyment from interactions, and the reflection about the methods employed and the questions posed to the stakeholders (see appendix 3). During the workshops in Solsona (in 2013) and Inverness (in 2016) researchers recognised that they had become aware of forest owners" "real opinions" when talking to them about their problems, and that they could link these perspectives to forest owner types (i.e. traditional and non-traditional). In the workshops, researchers also mentioned that learning about the regions they were visiting prompted them to contemplate further forest management practices implemented in their own countries, which in turn further improved their understanding of forest management. The interaction with forest owners also exposed the relevance of traditional knowledge, and researchers highlighted the need to acknowledge this in their future research. Researchers mentioned that it was "really interesting" to meet local stakeholders and to understand their relation with forests and forest-related policies. Furthermore, this allowed researchers to acquire a comprehensive picture of the forest sector in the regions visited, and across different scales, namely, the local level through forest owners, and the regional level, through policy-makers. In the workshop in Solsona, researchers recognised that the topics learned due to the interaction with stakeholders were relevant to the work undertaken within the FACESMAP working groups (see appendix 4). Given its interactive, iterative and flexible characteristics, the Travellab evolved from site to site through the adoption of the recommendations provided by the group reflections. Researchers recognised that "collectively designing and reflecting upon the process is 
valuable" and that it "helped the group to have joint focus". In general, researchers considered the Travellab to be "a distinct improvement compared to other COST Actions" and that it was "the most important part of such a meeting". These quotes provide good evidence that researchers who participated in the Travellab activities have taken the learning obtained during the Travellab and changed their behaviour in terms of setting more relevant research questions and of adopting transdisciplinary and action research approaches instead of conventional (e.g. disciplinary) approaches, as a result of their participation in the Travellab. This is essential when dealing with wicked environmental problems such as the implementation of sustainable forest management.

\subsection{Shortcomings of the Travellab}

The observation notes showed recurrent recommendations, suggesting these were not implemented throughout the process (Table 1). The observation notes also showed researchers' concerns about methodological shortcomings such as poor interviewing techniques (e.g. asking closed questions instead of open questions) or the participation of powerful stakeholders who might have prevented the participation of other less powerful stakeholders.

[Table 1 here]

Some researchers considered that the "The learning lab idea [was] unnecessarily complicated", and that it would be better to have "honest excursions with free questions, as we do not have coherent given questions in the WGs!" and "to embrace [difference] rather than to keep to a limited and quackery developed frame!" Some researchers also perceived that the approach was "forced and over-controlled" and felt that the amount of time dedicated to the Travellab activities was too limited - "at times beaten by the clock".

Some researchers thought there were no opportunities for individual reflection, including the preparation of individual summaries as well as the exchange of ideas between working groups. Researchers noticed that the Travellab needed "a system that allows/facilitates prompt feedback" to better support the development of the method. There were concerns 
568

569

570

571

572

573

574

575

576

577

578

579

580

581

582

583

584

585

586

587

588

589

590

591

592

593

594

595

596

597

about the quality of the data collected and some suggested recording the discussions with the stakeholders in the future to ensure the quality of the data collected. Researchers proposed that all parties involved (researchers and stakeholders) should have the objectives of the Travellab clarified beforehand and should have a common understanding of the approach. Researchers also considered that it would be "important not only to extract information from the stakeholders but also to give them something".

\section{Discussion}

The main objective of the Travellab was to enhance knowledge production by creating a shared learning space where researchers from various research backgrounds and nationalities interacted with stakeholders and worked as a community of practice to codesign research questions, which can be relevant to the development of future forestrelated policies. This differs from the traditional one-way approach of knowledge and technology transfer from researchers to agricultural and forestry advisors, and then to land users, which is still practiced in many areas but considered obsolete by many authors (e.g. Fry et al., 2003; Gabathuler et al., 2011). Such top-down ventures, which do not properly integrate stakeholders' interests, are common in the context of Swedish forestry, for example (Wallin et al., 2016). In fact, there is an increasing recognition that research related to tackling wicked problems such as sustainable forest management should take into consideration those closest to the land, namely individuals, land managers, communities and businesses, in order to reflect local needs and circumstances (Duckett et al., 2016; Wallin et al., 2016) and the Travellab followed this idea. According to Schwilch et al. (2012), there is an immediate need for practical tools that enable stakeholder learning and foster sustainable forest management. Schneider et al. (2009) suggests that that social learning, which comprises co-production of knowledge by stakeholders and researchers through a shared learning space, is essential to ensure the implementation of sustainable land management. The Travellab approach developed and implemented within the COST Action FACESMAP, created this shared learning space and imprinted structure and rigour to the interaction between researchers and stakeholders, maintaining the same thematic foci 
across countries over a period of several years (2013-2016). This article ascertains the main advantages of the Travellab:

- It favoured a conscious selection of the field sites to visit through liaison with local hosts and of the stakeholders to interact with via stakeholder analysis;

- It structured field visits co-organised by the Travellab task group and the local hosts;

- It established a link between the FACESMAP research questions and the questions asked to stakeholders during the Travellab activities;

- It used diverse stakeholder interaction techniques;

- It adjusted to local contexts and in response to suggestions from participants, and;

- It allowed time for group reflection about the Travellab approach, the information acquired and the learning process.

Observation notes confirmed that quality of interaction between researchers and stakeholders was enhanced by the implementation of the Travellab. Campbell et al. (2006) found out that learning capability of groups increase through facilitation, which is a way of structuring and supporting interaction and communication. Splitting the whole group into smaller subgroups was also an essential part of achieving higher quality interactions. Bailey et al. (2006) suggested that the optimal number of participants in a discussion group is between 15 and 20. In the Travellab the whole group of FACESMAP participants was divided into smaller groups of no more than 20 people in order to stimulate participants' attention during the discussions with stakeholders and to promote quality interaction.

Researchers from different disciplinary backgrounds learned about several topics during the field visits such as local context, management approaches, forest threats, knowledge systems, the role of incentives and forest policies and forest owners' values. The effectiveness of the Travellab in contributing to increase the awareness of a relevant number of researchers ( 70 people) about the diversity of circumstances across Europe (from different forest owners' perceptions, to different forest management styles in Europe) might have a positive impact on policy development in their own countries. Pohl (2011) considers that "ideal" transdisciplinary approaches should relate to socially relevant issues, transcend and integrate disciplinary paradigms, involve participatory research, and search 
for a unity of knowledge. Understanding diversity is extremely important and it might discourage researchers from advocating a "one-fits all" solution to policy-makers.

The Travellab allowed scientists to learn through experience and to reflect upon the gained knowledge both individually, through the notes taken and in a group setting during the working group meetings, plenaries and specific workshops to evaluate the effectiveness of the Travellab approach (Solsona, Inverness). Individual views challenged other members of the group and this contributed to greater joint learning. According to Prager and Creaney (2017) learning from experience can be based on the researchers' own experience, but can also be based on observing someone else's experience. Experiential learning was maximised by a combination of visiting forests sites, discussing with the forest owners on-site, and interacting with the wider range of stakeholders.

Although the Travellab was dynamic and constantly being adapted according to the specificities of each region visited, a set of recurrent recommendations from the participants (see Table 1 ) indicates that reframing was not always possible. This was mainly due to time constraints within the structure of the COST Action and resource limitations in the host countries. However, even though some recommendations were not implemented, the Travellab approach triggered individual and collective reflection about these recommendations. According to Harris (2014), summarising information improves learning since it makes individuals think about the information obtained, which parts are more important, and forces them to rewrite in their own words the main points or ideas. Therefore, learning also happened during note taking in the field visits and carousels, when researchers were summarising the main opinions generated during reflection and discussion within each working group, and further, when these summaries were presented to the plenary. Nevertheless, some researchers believed that the Travellab approach should have allocated more time for individual reflection, preparation of individual summaries and more exchange of ideas between working groups. Evans (1990) considers that a lack of selfreflection is a barrier for societal learning and hinders the transition to more sustainable resource management. On the other hand, this would have required more documentation on the process, which would have further increased the already large amount of data collected, leading to a greater allocation of time and resources being committed to data analysis (Collins et al., 2004). 
663 The specific workshops that took place in Solsona in 2013 and Inverness in 2016 provided the groundwork for a critical discussion about the effectiveness of the method to improve researchers' learning. Researchers mentioned that the Travellab worked as an anchor, i.e. an image they could connect to certain insights (cp. "Got a picture of how the forest sector works in this part of Europe", see appendix 4) that immediately transported the participants back to their experience in each region. According to Behrendt \& Franklin (2014), experiential learning is authentic, first-hand, sensory-based learning. The Travellab facilitated, therefore, a more memorable experience in comparison to listening to oral presentations or reading research results. For Haider et al. (2017), skills in facilitation, participatory approaches and the ability to see 'the big picture' are valuable skills in sustainability science.

\subsection{Limitations of the Travellab approach and recommendations for future} implementation

As the primary objective of the Travellab was to enhance researchers' learning about forest ownership and management issues, the quality of data collected during the Travellab might be questionable and to undertake further analysis for scientific publication purposes might be challenging. This highlights the fact that there are clear trade-offs between designing the process for high quality data collection and designing the process to encourage the involvement of more researchers in data collection activities. The former would require professional facilitation assigning the roles to more experienced researchers but it would risk disengagement of the remaining group and consequently lower levels of joint and individual learning and participation.

Such as other inter- and transdisciplinary approaches, the Travellab should have promoted knowledge exchange, i.e. continuous exchange between researchers and local stakeholders (Brandt et al., 2013; Zscheischler and Rogga, 2015). However, the pressure from the project goals and time constraints in delivering the scientific targets limited the capacity to favour two-way communication. One-way, question-answer interaction was favoured instead. The delivery of feedback to local stakeholders was left to the initiative of the local hosts, their 
own resources and own methods outside the Travellab framework. Nevertheless, many stakeholders expressed that they enjoyed the experience and that the questions triggered new insights about forest ownership, management, policy and their own work.

\section{Another potential limitation relates to power relations among the stakeholders and} researchers. The implementation of the Travellab relied on the local hosts as translators, which might have distorted the answers provided by stakeholders. Local hosts were often researchers themselves and potentially incorporated their own views or beliefs into the translation process, which might have contributed to answer bias. Thurmond (2001) names this the holistic fallacy, which occurs when the researcher believes inaccurately that the beliefs of the individual are similar to the beliefs of the researcher. In order to avoid such biases, the engagement of professional or otherwise independent facilitators is advisable.

Furthermore, in some situations, different types of stakeholders, with different power and influence were in the same room (e.g. advisory services, state authorities, forest owners) and might have prevented less powerful stakeholders to express their opinions. Even though stakeholders were usually divided into different groups in the field trips and carousels, it was not always possible to separate stakeholders due to time or other organisational constraints. Furthermore, it may be insightful to organise panel discussions purposely including different stakeholder groups. Such situations need to be explicitly considered in the interpretation of results.

\section{Conclusions}

The Travellab approach is a problem-driven process of inquiry that put interaction between researchers and stakeholders at the centre of COST Action FACESMAP. The Travellab was designed as an inclusive process of continuous learning and exchange between FACESMAP participants and different regional and local stakeholder types in several European countries. Throughout the implementation, individual observations and joint reflections were systematically documented for further refinement and analysis of the benefit of the approach to improve researcher's learning and to trigger change. The Travellab allowed project participants to experience the physical environment as well as the socio-economic 
and cultural contexts surrounding the cities where the project meetings took place, during the field trips and carousels with stakeholders. The Travellab created a space for FACESMAP participants to learn more in depth about the implications of ownership and policy changes on sustainable forest management in Europe and this might have a positive impact in dealing with this wicked problem in the future. Since local context matters in the design of solutions to wicked environmental problems, such as sustainable forest management, this learning space favoured quality engagement with stakeholders in their physical and social environment and consequently joint learning about relevant research questions to investigate in the future. Duckett et al. (2016) considers that given the scale of challenges such as the implementation of sustainable forest management, any positive impact resulting from strategies to tackle wicked problems, even where it may exist, is extremely difficult to assess. The Travellab, and this article, made a substantial effort to assess impact by systematically recording and analysing evidence on how learning was occurring during the process of implementation of the approach. This evidence indicates that the Travellab favoured joint learning and researchers' behaviour change, which may positively contribute to the implementation of successful strategies that support sustainable forest management, in their countries, in the future.

The Travellab triggered researchers to rethink the underlying assumptions and norms associated with conventional research (e.g. disciplinary). The Travellab strongly encouraged the adoption of a combination of participatory research methods, which included the dissemination of introductory materials (handouts/presentations), the use of a comprehensive, iterative and interactive format, walking interviews, carousels and the inclusion of joint reflection sessions. The Travellab favoured inter- and transdisciplinary research approaches, which are key-approaches to deal with wicked environmental problems, but often undervalued in academia. The Travellab was developed specifically for a large COST Action (FACESMAP), carried out over four years, and incorporated an international network of around 70 participants with different disciplinary backgrounds from 30 European countries. The approach added greater value to casual stakeholder interaction, and its implementation in similar research projects is highly recommended. The process is particularly suited to large, longer term (multi-year), 
collaborative, international and interdisciplinary projects with the aim of connecting research, policy and practice. The Travellab approach may also be suitable for smaller national projects, with fewer researchers involved and without the language barrier to limit interaction quality to such an extent. The basic set of interactive methods integrated within the Travellab can also be adapted to scientific excursions/field trips organised within one-off conferences for a diverse range of participants. Furthermore, the approach can also be adapted to any research topic(s) in or outside the forestry field.

Unlike many research projects, the Travellab did not fall short in applying the basic principles and up-to-date methods for inter- and transdisciplinary research (Brandt et al. 2013; Zscheischler and Rogga 2015) as it considered stakeholder participation seriously. The Travellab addressed most of the requirements for effective participation, such as early and fair involvement, transparency and openness of the decision-making process (Newig, 2007). Similarly to other inter- and transdisciplinary research projects and experiences, the Travellab approach also faced many content-related and organisational challenges, namely those related to the integration of different knowledge types (from practice and research and from different disciplines) and disincentives from the science system (e.g. universities) for researchers to invest time in inter- and transdisciplinary research.

Some limitations of the Travellab are related to two typical challenges, which are often found in inter- and transdisciplinary research: First, the limited resources led to research dominance over capacity building and mutual learning. A review study found that in many transdisciplinary research projects scientists and practitioners do exchange knowledge but real stakeholder empowerment is rare (Brandt et al. 2013). Second, more attention should be paid into how different interests and power relations between stakeholders may influence the interaction patterns (Maasen et al. 2006; Weiss et al. 2011). Therefore, it is recommended to engage experienced facilitators, consider stakeholders' interests when planning field visits and carousel discussions, and to consider their power relations when interpreting the discussion results. One specific challenge found during the Travellab was the trade-off between a more scientifically oriented process (Wallin et al. 2016) versus the aim of successful joint learning of the whole group of researchers and the stakeholders involved in the process (Schauppenlehner-Kloyber and Penker 2015). In order to ensure 
joint learning amongst researchers and stakeholders, the planning of future Travellabs should prioritise the following points:

- Clarification of the aims of the Travellab approach at the start of the project, allocation of sufficient time and financial resources, strong leadership and ensure adaptive project management. If possible, dedication of a whole Work Package to the approach;

- Engagement of researchers with experience in facilitation techniques or professional facilitators to assist stakeholder interaction (experienced researchers may also train researchers with less experience in participatory methods so these can facilitate the interactions);

- Involvement of researchers and stakeholders at the different stages of the process, including the development of the methodological set-up, simultaneous reflections and the discussion of final conclusions;

- Summary and iterative assessment of the results at the end of each Travellab and provision of space for group and individual reflection at regular intervals and whenever suitable;

- Favouring knowledge exchange between researchers and stakeholders instead of one-way interactions by allocating appropriate time resources and considered multiple formats.

\section{Acknowledgements}

This paper was written as a part of the COST Action FP1201 Forest Land Ownership Changes in Europe: Significance for Management and Policy (FACESMAP). The authors want to thank all FACESMAP colleagues for their active involvement, collaboration and contribution to Travellab, as well as in the project. Special thanks to the local organisers of the FACESMAP meetings and Travellabs, as well as to all stakeholders for their commitment, and steadfast enthusiasm, which made these meetings so pleasurable and productive. 


\section{References}

821

Allen, G. M., Gould, E. M. (1986). Complexity, wickedness, and public forests. Journal of Forestry (84)4, 20-24.

Argyris, C., Putnam, R., MacLain-Smith, D. (1985). Action science. San Francisco: JosseyBass.

Armitage, D., Marschke, M., Plummer, R. (2008). Adaptive co-management and the paradox of learning. Global Environmental Change 18, 86-98.

Atieno, O. P. (2009). An analysis of the strengths and limitation of qualitative and quantitative research paradigms. Problems of Education in the 21st Century, 13, 13-18.

Bailey, A.P., Garforth, C.J., Angell, B., Scott, T., Beedell, J., Beechener, S., Rana, R.B., (2006). Helping farmers adjust to policy reforms through demonstration farms: lessons from a project in England. Journal of Farm Management 12(10), 613-625.

\section{Bandura, A. (1977). Social learning theory. Englewood Cliffs, NJ: Prentice Hall.}

Barab, S., Squire, K. (2004). Design-Based Research: Putting a Stake in the Ground. The Journal of the Learning Sciences 13(1), 1-14.

Behrendt, M., Franklin, T. (2014). A Review of Research on School Field Trips and Their Value in Education. International Journal of Environmental \& Science Education 9, 235-245.

Bergmann, M., Brohmann, B., Hoffmann, E., Loibl, M. C., Rehaag, R., Schramm, E., Voss, J.-P. (2005). Quality Criteria of Transdisciplinary Research: A Guide for the Formative Evaluation of Research Projects, Frankfurt am Main: Institute of Social-Ecological Research.

Black, A. (2000). Extension theory and practice: A review. Animal Production Science 40(4), 493-502.

Boeckmann, T., Dorsch, P., Hoffmann, F., Ohlhorst, D., Schumacher, U., Wulff, J. (2005) Zwischen Theorie und Praxis. Anregungen zur Gestaltung von Wissenschafts-PraxisKooperationen in der Nachhaltigkeitsforschung. T. U. B. Zentrum Technik und Gesellschaft Berlin, ZTG. Discussion Paper 17/05: 40.

Bowditch, E.A.D., McMorranb, R., Bryce, R., Smith, M. Perception and partnership: Developing forest resilience on private estates. Forest Policy and Economics (this issue). 
Brown, I., Everard, M. (2015). A working typology of response options to manage environmental change and their scope for complementarity using an Ecosystem Approach. Environmental Science and Policy 52, 61-73.

866

Bryman, A. (2011). Business research methods. Bell, Emma, 1968- (3rd ed.). Cambridge:

Bryson, J. M. (2004). What to do when Stakeholders matter, Public Management Review, 6:1, 21-53.

Buizer, M., Arts, B., Kok, K. (2011). Governance, scale, and the environment: the importance of recognizing knowledge claims in transdisciplinary arenas. Ecology and Society 16(1), 21.

Burnette, B., DeHose, J. (2008). The land has wisdom. In: Fortmann, L. (Ed). Participatory research in conservation and rural livelihoods: doing science together. Blackwell, Oxford.

Burton, R.J.F., Kuczera, C., Schwarz, G. (2008). Exploring farmers' cultural resistance to voluntary agri-environment schemes. Sociologia Ruralis 48 (1), 16-37.

Campbell, S., Counsell, D., Friend, D., Thompson, R., Ackland, S., Barrington, S., (2006). Monitor farms as a tool for practice change e the $8 \times 5$ Wool Profit Program experience. Australiasian Pacific Extension Network. The Regional Institute Online Publishing. of the US Inland Northwest: A Classic 'Wicked Problem' in Public Land Policy. Journal of Forestry 105(5), 239-44.

889

Checkland, P., Holwell, S. (1998). Action Research: Its Nature and Validity. Systemic Practice and Action Research 11(1).

Chevalier, J.M., Bucklas, D.J. (2011). A Handbook for Participatory Action Research, Planning and Evaluation. Ottawa, Canada: SAS2 Dialogue.

Collins, A., Joseph, D., \& Bielaczyc, K. (2004). Design research: Theoretical and methodological issues. Journal of the Learning Sciences, 13(1), 15-42.

Cronin, K. (2008). Transdisciplinary Research (TDR) and Sustainability: Overview report prepared for the Ministry of Research, Science and Technology (MoRST), New Zealand. 
901

902

903

904

905

906

907

908

909

910

911

912

913

914

915

916

917

918

919

920

921

922

923

924

925

926

927

928

929

930

931

932

933

934

935

936

937

938

939

940

941

Cundill, G., Cumming, G.S., Biggs, D., Fabricius, C. (2012). Soft Systems Thinking and Social Learning for Adaptive Management. Conservation Biology, 26(1), 13-20.

de Vries, B. (2013). Sustainability science. Cambridge University Press, Cambridge.

Daniels, S., Walker, G. B. (2001). Working through environmental conflict: The collaborative learning approach, Westport, C.T. Praeger.

Duckett, D., Feliciano, D., Martin-Ortega, J., Munoz-Rojas, J. (2016). Tackling wicked environmental problems: The discourse and its influence on praxis in Scotland. Landscape and Urban Planning 154, 44-56.

Durham E., Baker H., Smith M., Moore E. \& Morgan V. (2014). The BiodivERsA Stakeholder Engagement Handbook. BiodivERsA, Paris.

EU (2013). A new EU Forest Strategy: for forests and the forest-based sector. Communication from the commission to the European Parliament, the Council, the European Economic and Social Committee and the Committee of the regions. Brussels 20.09.2013. Available at: http://eur-lex.europa.eu/resource.html?uri=cellar:21b27c38-21fb11e3-8d1c-01aa75ed71a1.0022.01/DOC 1\&format=PDF (accessed 26/01/2018).

Evans, J. (1990). Bias in Human Reasoning: Causes and Consequences. Psychology Press, UK.

Evans, J., Jones, P., 2011. The walking interview: methodology, mobility and place. Applied Geography, 31, 849-858.

Fazey, I., Fazey, J. A., Fazey, D. M. A. (2005). Learning more effectively from experience. Ecology and Society 10(2), 4.

Feliciano, D., Bouriaud, L., Brahic, E., Deuffic, P., Dobsinska, Z., Jarsky, V., Lawrence, A., Nybakk, E., Quiroga, S., Suarez, C., Ficko, A. (2017). Understanding private forest owners' conceptualisation of forest management: Evidence from a survey in seven European countries. Journal of Rural Studies, 54, 162-176.

Fleming, A., Vanclay F. (2010). Farmer's responses to climate change and sustainable agriculture. Agriculture for Sustainable Development 30(1), 11-19.

Folke, C., Hahn, T., Olsson, P., Norberg, J., 2005. Adaptive governance of social-ecological systems. Annual Review of Environment and Resources 30 (1), 441-473. 
Fortmann, L., Ballard, H. (2011). Sciences, knowledges, and the practice of forestry. European Journal of Forest Research, 130, 467-477.

944

945

946

947

948

949

950

951

952

953

954

955

956

957

958

959

960

961

962

963

964

965

966

967

968

969

970

971

972

973

974

975

976

977

978

979

980

981

982

983

984

Freeman, R.E. (1984). Strategic Management: a Stakeholder Approach. Pitman, Boston.

Fry, P., Seidl, I., Théato, A., Kläy, A., Bachmann, F. (2003). Vom Wissenstransfer zum Wissensaustausch: Neue Impulse für den Boden- und Biodiversitätsschutz in der Landwirtschaft. GAIA e Ecological Perspectives for Science and Society 12 (2), 148-150.

Garmendia, E., Stagl, S. (2010). Public participation for sustainability and social learning: concepts and lessons from three case studies in Europe. Ecological Economics 69, 17121722.

Gabathuler, E., Bachmann, F., Kläy, A. (2011). Reshaping Rural Extension. Learning for Sustainability (LforS) e An Integrative and Learning-based Advisory Approach for Rural Extension with Small-Scale Farmers. Margraf Publishers, Weikersheim.

Gibbons, M., Novotny, H. (2001). The Potential of Transdisciplinarity. In J.T. Klein, W. Grossenbacher-Mansuy, R. Häberli (Eds.) Transdisciplinarity: Joint Problem Solving among Science, Technology, and Society. An Effective Way for Managing Complexity, Basel: Birkha user, 67-80.

Haider, L.J., Hentati-Sundberg, J., Giusti, M., Goodness, J., Hamann, M., et al (2017). The undisciplinary journey: early-career perspectives in sustainability science. Sustainability Science. 13(1), 191-204.

Hargrove, R. (2002). Masterful Coaching. Revised Edition. Jossey-Bass/Pfeiffer, Wiley, USA.

HarmoniCOP (2015). Learning together to manage together - improving participation in water management. HarmoniCOP team, University of Osnabruck, Institute of Environmental Systems Research, Barbarastr 12, 49069 Osnabruck, Germany.

Harris, R. (2014). Learning Strategy 3: Summarizing. Version Date: February 27, 2014. Available at: https://www.virtualsalt.com/learn3.html

Hirsch Hadorn, G., Bradley, D., Pohl, C., Rist, S., and Wiesmann, U. (2006). Implications of transdisciplinarity for sustainability research. Ecological Economics, 60, 119-128.

Ison, R., Roling, N., Watson, D. (2007).Challenges to science and society in the sustainable management and use of water: investigating the role of social learning. Environmental Science \& Policy 10, 499-511. 
Jantsch, E. (1972). Towards Interdisciplinarity and Transdisciplinarity in Education and Innovation, Interdisciplinarity: Problems of Teaching and Research in Universities, Paris: Centre for Educational Research and Innovation.

Johnson, D. W., Johnson, F. P. (1987). Joining together: Group theory and group skills (3rd ed.). Englewood Cliffs, NJ: Prentice Hall.

991

Kemmis, S. (1981). Action research in prospect and retrospect. In Kemmis, S., Henry, C., Hook, C., McTaggart, R. (Eds.). The action research reader (pp.11-31).Geelong, Australia: Deakin University Press.

995

Keen, M., Brown, V. A., Dyball, R. (2005). Social learning in environmental management: towards a sustainable future. Earthscan, London, UK.

998

Lang, D. J., Wiek, A., Bergmann, M., Stauffacher, M., Martens, P., Moll, P., et al. (2012).

1000 Transdisciplinary research in sustainability science: Practice, principles, and challenges.

1001 Sustainability Science, 7(1), 5-43.

1002

1003

Lawrence, A., Dandy, N. (2014). Private landowners' approaches to planting and managing 1004 forests inthe UK: What's the evidence? Land Use Policy, 36, 351-360.

1005

1006

Lachapelle, P.R., McCool, S.F., Patterson, M.E. (2003) Barriers to effective natural resource

1007 planning in a"messy"world. Society and Natural Resources 16, 473-490.

1008

1009

Lee, K.N. (1993). Compass and gyroscope: integrating science and politics for the 1010 environment. Island Press, Washington, DC.

1011

1012

1013

1014

Leeuwis, C., R. Pyburn, Röling, N. (2002). Wheelbarrows full of frogs: Social learning in rural resource management: International research and reflections. The Netherlands: Koninklijke van Gorcum.

1015

1016

Maasen, S., Lengwiler, M. and Guggenheim, M. (2006). Practices of transdisciplinary 1017 research: Close(r) encounters of science and society', Science and Public Policy 33(6), 3941018 398.

1019

1020

1021

Measham, T. (2009). Social learning through evaluation: A case study of overcoming constraints for management of dryland salinity. Environmental Management 43, 1096-1107.

Newig, J. (2007). Does public participation in environmental decisions lead to improved environmental quality. Communication, Cooperation, Participation: Research and Practice for a Sustainable Future, 1, 51-71.

1026 
1027

1028

1029

1030

1031

1032

1033

1034

1035

1036

1037

1038

1039

1040

1041

1042

1043

1044

1045

1046

1047

1048

1049

1050

1051

1052

1053

1054

1055

1056

1057

1058

1059

1060

1061

1062

1063

1064

1065

1066

Pahl-Wostl, C. (2006). The importance of social learning in restoring the multifunctionality of rivers and floodplains. Ecology and Society, 11(1),10.

Pahl-Wostl, C., Craps, M., Dewulf, A., Mostert, E., Tabara, D., Taillieu, T. (2007). Social learning and water resources management. Ecology and Society, 12(2), 5.

Pohl, C. (2011). What is progress in transdisciplinary research? Futures, 43, 618-626.

Prager, K., Creany, R. (2017). Achieving on farm practice change through facilitated group learning: Evaluating the effectiveness of monitor farms and discussion groups. Journal of Rural Studies 56, 1-11.

Pretty, J. N., Guijt, I., Scoones, I., Thompson, J. (1995). A Trainers' Guide to Participatory Learning and Interaction, IIED Participatory Methodology Series No. 1 (London, International Institute for Environment and Development, 1995).

Reed, M. (2008). Stakeholder participation for environmental management: A literature review. Biological conservation, 141, 2417-2431.

Reed, M., Evely, G., Cundill, I., Fazey, J., Glass, A., Laing, J., Newig, B., Parrish, C., Prell, C., (2010). What is social learning? Ecology and Society, 15:4: r1.

Rittel, H. W. J., Webber, M. M. (1973). Dilemmas in the general theory of planning. Policy Sciences, 4, 155-169

Rodela, R., Cundill, G., Wals, A.E.J. (2012). An analysis of the methodological underpinnings of social learning research in natural resource management. Ecological Economics 77, 1626.

Robinson, J. (2008). Being undisciplined: transgressions and intersections in academia and beyond. Futures 40(1),70-86.

Roux, D.J., Stirzaker, R.J., Breen, C.M., Lefroy, E.C., Cresswell, H.P. (2010) Framework for participative reflection on the accomplishment of transdisciplinary research programs. Environmental Science and Policy, 13, 733-741.

Ruppert-Winkel, C., Arlinghaus, R., Deppisch, S., Eisenack, K., Gottschlich, D., Hirschl, B., Matzdorf, B., Molders, T., Padmanabhan, M., Selbmann, K., Ziegler, R., Plieninger, T. (2015) Characteristics, emerging needs, and challenges of transdisciplinary sustainability science: experiences from the German Social-Ecological Research Program. Ecology and Society 20(3), 13. 
Schauppenlehner-Kloyber, E., Penker, M. (2015). Managing group processes in transdisciplinary future studies: How to facilitate social learning and capacity building for self-organised action towards sustainable urban development? Futures 65, 57-71.

Scherhaufer, P. (2014) Bridging the Gap Between the Theory and Practices of Stakeholder Participation in Integrated Vulnerability Assessments of Climate Change. Syst Pract Action

1075

Schneider, F., Fry, P., Ledermann, T., Rist, S. (2009). Social learning processes in Swiss soil protection e the 'from farmer e to farmer' project. Human Ecology 37, 475-489.

1078

Schophaus, M., Schön, S. and Dienel, H.-L. (eds.) (2004). Transdisziplinäres Kooperationsmanagement. Neue Wege in der Zusammenarbeit zwischen Wissenschaft und

Schwilch, U., Bachmann, F., Valente, S., Coelho, C., Moreira, J., Laouina, A., Chaker, M., Aderghal, M., Santos, P., Reed, M. (2012). A structured multi-stakeholder learning process for Sustainable Land Management. Journal of Environmental Management, 107, 52-63.

Scott, A., (2011). Focussing in on focus groups: effective participative tools or cheap fixes for land use policy? Land Use Policy, 28, 684-694.

1089

Slunge, D., Drakenberg, O., Ekbom, A., Göthberg, M., Knaggård, A. Sahlin, U. (2017). Stakeholder Interaction in Research Processes - a Guide for Researchers and Research Groups. University of Gothenburg. Gothenburg.

Stirling, A. (2006). Analysis, participation and power: justification and closure in 1095 1096 participatory multi-criteria analysis. Land Use Policy 23(1), 95-107.

The Design-Based Research Collective. (2003). Design-based research: An emerging paradigm for educational inquiry. Educational Researcher, 5-8.

Thurmond, V. (2001). The Point of Triangulation. Journal of Nursing Scholarship 33, 253-258.

Van den Akker, J., Gravemeijer, K., McKenney, S., \& Nieveen, N. (2006). Educational design research. Abingdon, Oxon: Taylor \& Francis. 669. 
1108

1109

1110

1111

1112

1113

1114

1115

1116

1117

1118

1119

1120

1121

1122

1123

1124

1125

1126

1127

1128

1129

1130

1131

1132

1133

1134

1135

1136

1137

1138

1139

1140

1141

1142

1143

1144

1145

1146

1147

Walter, A.L., Helgenberger, S., Wiek, A., Scholz, R.W. (2007). Measuring societal effects of transdisciplinary research projects: design and application of an evaluation method. Eval Program Plan, 30(4), 325-338.

Wallace, K.J., Wagner, C., Smith, M.J. (2016). Eliciting human values for conservation planning and decisions: a global issue. Journal of Environmental Management, 170, 160-168.

Wallin, I., Carlsson, J., Hansen, H. P. (2016). Envisioning future forested landscapes in Sweden - Revealing local-national discrepancies through participatory action research. Forest Policy and Economics, 73, 25-40.

Wang, F. \& Hannafin, M. J. (2005). Design-based research and technology-enhanced learning environments. Educational Technology Research and Development, 53(4), 5-23.

Weingart, P. and Stehr, N. (eds.) (2000). Practising Interdisciplinarity, Toronto: University of Toronto Press.

Weiss, G., Lawrence, A., Lidestav, G., Feliciano, D., Hujala, T. (2017). Changing Forest Ownership in Europe - Main Results and Policy Implications, COST Action FP1201 FACESMAP. Policy paper, EFICEEC-EFISEE Research Report. University of Natural Resources and Life Sciences, Vienna (BOKU), Vienna, Austria. 25 pages.

Weiss, G., Lawrence, A., Hujala, T., Lidestav, G., Nichiforel, L., Nybakk, E., Quiroga, S., Sarvašová, Z., Suarez, C., Živojinović I. (in press) Forest ownership changes in Europe: State of knowledge and conceptual foundations. Forest Policy and Economics. (this issue)

Weiss, G., Steiner, R., Eckmüllner, O. (2011). Assessing institutional frameworks of inter- and transdisciplinary research and education. Higher Education Policy 24, 499-516.

Winkel, G., Aggestam, F., Sotirov, M., Weiss, G. (2013): Forest Policy in the European Union. In: Pülzl, H., Hogl, K., Kleinschmit, D., Wydra, D., Arts, B., Mayer, P., Palahí, M., Winkel, G. Wolfslehner, B. (Eds): European Forest Governance: Issues at Stake and the Way Forward; What Science Can Tell Us 2, EFI, Joensuu, 52-63.

Živojinović, I., Weiss, G., Lidestav, G., Feliciano, D., Hujala, T., Dobšinská, Z., Lawrence, A., Nybakk, E., Quiroga, S., Schraml, U. (2015). Forest Land Ownership Change in Europe. COST Action FP1201 FACESMAP Country Reports, Joint Volume. EFICEEC-EFISEE Research Report. University of Natural Resources and Life Sciences, Vienna (BOKU), Vienna, Austria. 693 pages. 
1148 Zscheischler, J., S. Rogga (2015). Transdisciplinary in land use science. A review of concepts, 1149 empirical findings and current practices. Futures 65, p 28-44.

1150

1151 


\section{Learning about forest ownership and management issues in Europe while travelling: The Travellab approach}

Feliciano, D. ${ }^{1 *}$, Blagojević, D. ${ }^{2}$, Böhling, $\mathrm{K}^{3}$., Hujala, $\mathrm{T}^{4,5}$, Lawrence, A. ${ }^{6}$, Lidestav, G. ${ }^{7}$, Ludvig, A. ${ }^{8}$, Turner, T. $^{9}$, Weiss, G. $^{8}$, Zivojinovic, I. $^{8}$

$1^{1 *}$ Corresponding Author, Institute of Biological and Environmental Sciences, School of Biological Sciences, University of Aberdeen, 23 St Machar Drive, Aberdeen AB24 3UU, Scotland, UK

E-mail: diana.feliciano@abdn.ac.uk

${ }^{2}$ Senoina 5, 79101 Prijedor, Bosnia and Herzegovina

${ }^{3}$ Technical University of Munich, Hans-Carl-von-Carlowitz Platz 2, D-85354 Freising, Germany

${ }^{4}$ University of Eastern Finland, School of Forest Sciences, Yliopistokatu 7, 80100 Joensuu, Finland

${ }^{5}$ Natural Resources Institute Finland, Latokartanonkaari 9, Fl-00790 Helsinki, Finland

${ }^{6}$ Scottish School of Forestry, University of Highlands and Islands, IV2 5NA, Scotland

${ }^{7}$ Swedish University of Agricultural Sciences, Department of Forest Resource Management, SE 901 83, Umeå, Sweden

${ }^{8}$ European Forest Institute Central-East and South-East European Regional Office (EFICEEC-EFISEE), c/o University of Natural Resources and Life Sciences, Vienna, Feistmantelstr. 4, A-1180 Vienna, Austria

${ }^{9}$ William Smith Building, Keele University, Newcastle ST5 5BG 


\begin{abstract}
Forest management, with its diverse land-use and institutional pressures, can be considered a "wicked problem". Transdisciplinarity and social learning are considered relevant approaches of investigating "wicked problems" because they favour creative solutions, stakeholder involvement and the reframing of problems. Taking this into account, participant researchers in the COST Action FACESMAP developed the Travellab approach to enhance their understanding of forest ownership, management and policy across Europe. The Travellab favours interaction in a structured way, collection and analysis of the information discussed, reflection about the process and the topics learnt, and reframing of the discussion topics and of the interaction techniques. This article explores the effectiveness of the Travellab to enhance researchers' learning during interactions with stakeholders. The evidence presented indicates that the Travellab improved joint learning among researchers and enriched the quality of knowledge transferred, but did not effectively support knowledge exchange. Nevertheless, the Travellab added greater value to FACESMAP field visits when compared to ordinary field trips embedded in project meetings. The implementation of the Travellab approach in research projects of all sizes and international networks to improve group and individual learning is, therefore, highly recommended.
\end{abstract}

Keywords: wicked problems, transdisciplinarity, social learning, stakeholder, forest management 


\section{Highlights}

The Travellab is a transdisciplinary approach for stakeholder interaction

The Travellab exposed the diversity of forest issues across Europe

The Travellab improved joint learning

The Travellab added value to ordinary field trips embedded in COST Actions

The Travellab can adapt to research projects, one-off conferences or networks 


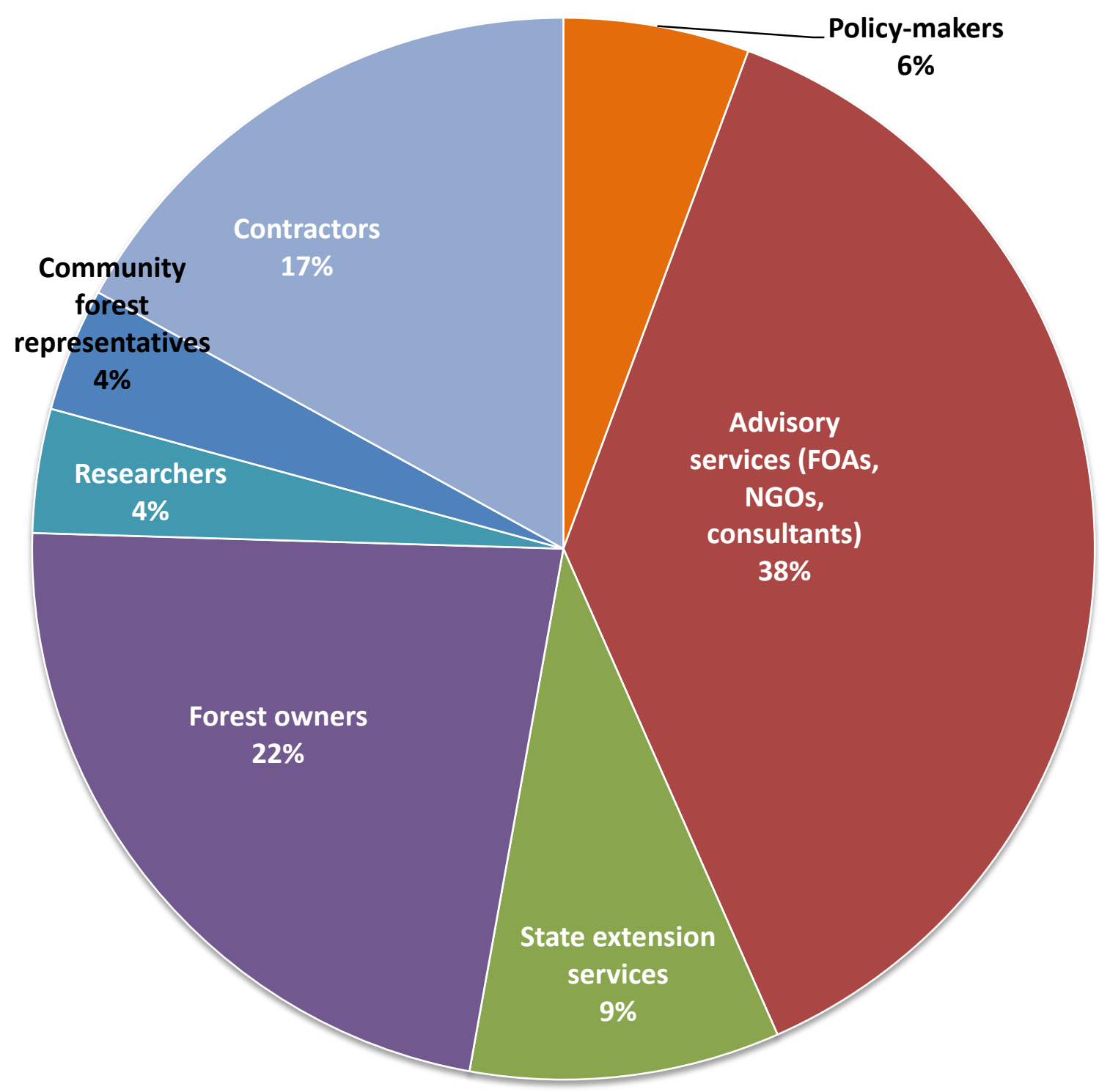

Figure 1 Stakeholders types involved in the Travellab

Note: FOAs - Forest Owners Associations, NGOs- Non-Governmental Organisations 
Table 1: Recommendations from note takers (observation notes)

\begin{tabular}{|c|c|c|}
\hline Site & Recommendations & Implementation status \\
\hline \multirow{4}{*}{ Solsona } & $\begin{array}{l}\text { Exchange knowledge about the situation in other countries } \\
\text { with local stakeholders }\end{array}$ & Not implemented \\
\hline & Allow all participants to ask questions & Implemented \\
\hline & $\begin{array}{l}\text { Discuss the "Travellab" and summarise the findings within } \\
\text { each working group }\end{array}$ & Implemented \\
\hline & Structure better the method & Attempted \\
\hline \multirow{5}{*}{ Helsinki } & $\begin{array}{l}\text { Present the context of the country, map the stakeholders, } \\
\text { prepare handouts before the "Travellab" }\end{array}$ & Implemented \\
\hline & $\begin{array}{l}\text { Formulate questions according to the Working Group } \\
\text { topics }\end{array}$ & Implemented \\
\hline & Choose themes to explore instead of questions to ask & Not implemented \\
\hline & $\begin{array}{l}\text { Do not join together forest owners and institution } \\
\text { representatives }\end{array}$ & Attempted \\
\hline & Have a moderator & Implemented \\
\hline \multirow{5}{*}{ Freiburg } & Learn interview techniques (avoid closed questions) & Attempted \\
\hline & Avoid repetition of questions & Attempted \\
\hline & Find comfortable venue to undertake the interviews & Attempted \\
\hline & Everybody should know their roles beforehand & Implemented \\
\hline & $\begin{array}{l}\text { Have someone responsible for management of the } \\
\text { interview (moderator) }\end{array}$ & Also recommended in Helsinki \\
\hline \multirow{4}{*}{ Zagreb } & Have a facilitator/moderator & $\begin{array}{l}\text { Recommended in Helsinki and } \\
\text { Freiburg }\end{array}$ \\
\hline & Avoid having all parties together as this creates tensions & Also recommended in Helsinki \\
\hline & Inform local hosts they should keep information short & Attempted \\
\hline & $\begin{array}{l}\text { Improve interaction between the “Travellab” Task Group } \\
\text { and the local hosts }\end{array}$ & Attempted \\
\hline \multirow{4}{*}{ Krakow } & Have a moderator & $\begin{array}{l}\text { Also recommended in Helsinki, } \\
\text { Freiburg and Zagreb }\end{array}$ \\
\hline & Use questions in a sensible way & Also recommended in Freiburg \\
\hline & Present the stakeholders (who is who) beforehand & Attempted \\
\hline & Have a good translator, who is not biased but neutral & $\begin{array}{l}\text { Not applicable as following } \\
\text { meeting to happen in Inverness } \\
\text { (UK) }\end{array}$ \\
\hline \multirow[b]{2}{*}{ Inverness } & Allocate roles to participants & Also recommened in Freiburg \\
\hline & $\begin{array}{l}\text { Allow for people who are really interested in the topic or } \\
\text { have a good "knowhow" ask questions so the conversation } \\
\text { is sustained }\end{array}$ & For future \\
\hline
\end{tabular}



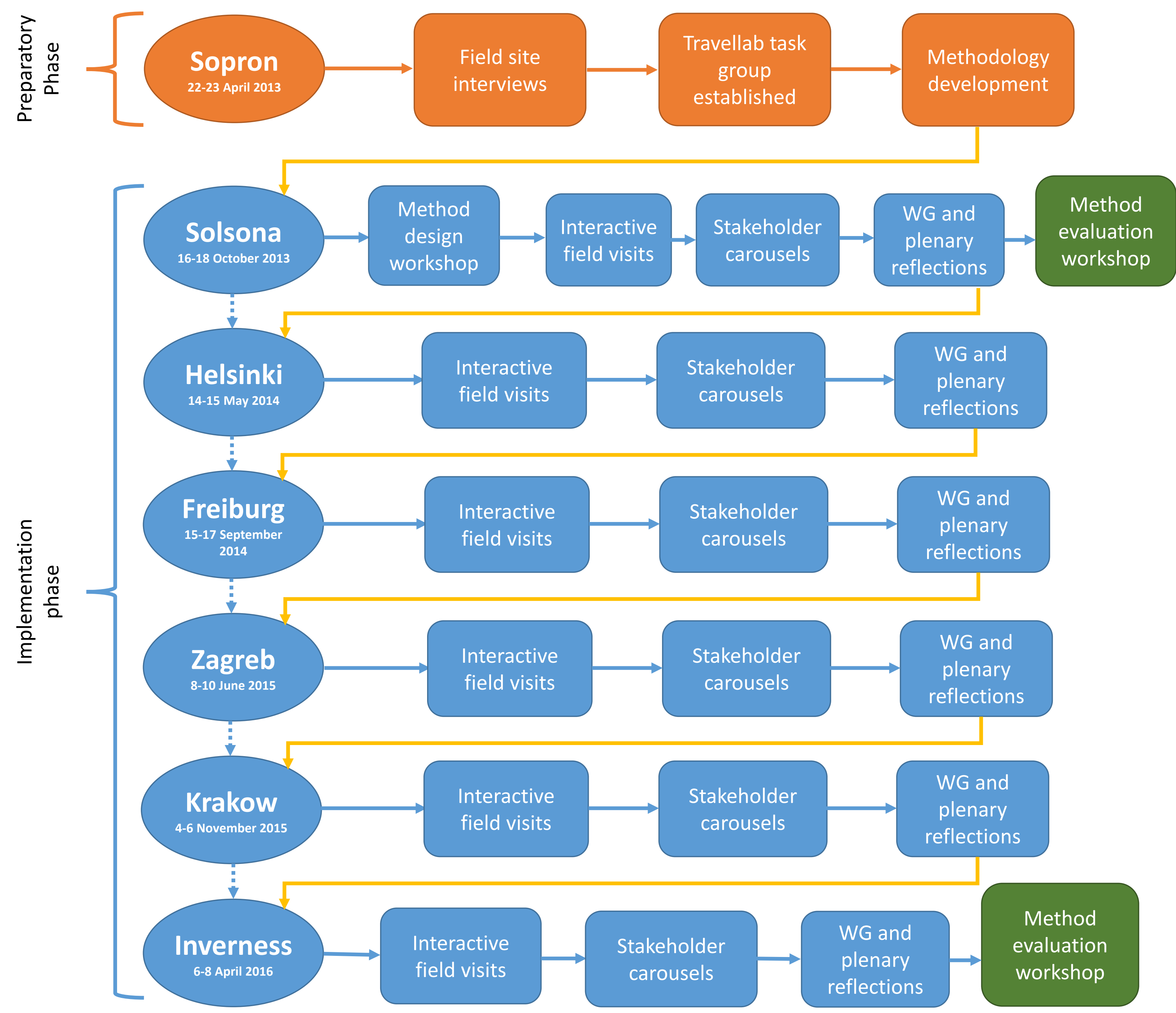


\section{Appendix 1}

\section{List of questions asked during the Travellab}

\section{Questions for private forest owners:}

- What are your feelings towards your forest property?

- What are your sources of income?

- What does being the forest owner mean to you?

- What are the property rights restrictions now and how do they compare with those in the past?

- What type of forest owner do you consider yourself (traditional/non-traditional)?

- If you had 3 wishes to improve forestry in the region, what would they be?

- What changes related to your forest or your business occurred in the past 5 years?

\section{Questions for other stakeholders types:}

What do you consider to be the differences between traditional forest owners and non-traditional forest owners?

- What role do incentives play in regional forest management?

- What is your role in in policy making?

- What are the biggest challenges that you face in your job/role related to forestry?

- What are the biggest challenges faced by PFOs in this region/country? 


\section{Appendix 2}

\section{Main topics learned during the Travellab}

\begin{tabular}{|c|c|c|}
\hline Topics learnt & Typical quotes extracted from content notes illustrate well the topics discussed & Site \\
\hline Local context & $\begin{array}{l}\text { "The forest has declined in terms of importance on the farm, agriculture now more } \\
\text { profitable (...) it is not profitable any more. Thirty years ago they introduced cattle } \\
\text { (...) this is their main income at the moment." }\end{array}$ & Solsona \\
\hline $\begin{array}{l}\text { Forest attitudes } \\
\text { towards forest } \\
\text { ownership }\end{array}$ & $\begin{array}{l}\text { "There is a strong connection with the forest, especially with the community. The } \\
\text { members of the forest community are willing to help/support the forest technician } \\
\text { in his work." }\end{array}$ & Krakow \\
\hline Forest uses & $\begin{array}{l}\text { "Due to good prices for wood and the combination of the revenues from the } \\
\text { agricultural production they lived well after the war (forestry and farming are closely } \\
\text { connected)“. }\end{array}$ & Freiburg \\
\hline $\begin{array}{l}\text { Perceptions of } \\
\text { "traditional”vs „non- } \\
\text { traditional“ }\end{array}$ & $\begin{array}{l}\text { „Traditional forest owners live locally and derived their income from agricultural and } \\
\text { forest land.“ }\end{array}$ & Helsinki \\
\hline $\begin{array}{l}\text { Management } \\
\text { approaches }\end{array}$ & $\begin{array}{l}\text { "The main goal of the father was to develop the diverse portfolio of services } \\
\text { (farming, forestry, wooden chips, thermic and hydro plants, restaurant). They have } \\
\text { already achieved a lot of these goals". }\end{array}$ & Inverness \\
\hline Challenges & $\begin{array}{l}\text { "He sees the greatest challenge the communication with buyers and operators but } \\
\text { feels that his proximity to the forest made this easier for him than others". }\end{array}$ & Krakow \\
\hline $\begin{array}{l}\text { Advisory/knowledge } \\
\text { systems }\end{array}$ & $\begin{array}{l}\text { "The Centre Tecnològic Forestal de Catalunya (CTFC) is important to keep the } \\
\text { management knowledge alive." }\end{array}$ & Solsona \\
\hline $\begin{array}{l}\text { Forest policies and } \\
\text { role of incentives }\end{array}$ & $\begin{array}{l}\text { "He finds the environmental policies are very restrictive. His land would have been a } \\
\text { good site for wind turbines but he isn't allowed to build them." }\end{array}$ & Freiburg \\
\hline Gender & $\begin{array}{l}\text { "There are not many female forest owners in the area and it feels good to be a } \\
\text { woman owning a forest as the traditional male foresters like to help her." }\end{array}$ & Zagreb \\
\hline
\end{tabular}




\section{Appendix 3}

Observations about the effectiveness of the Travellab

\begin{tabular}{|c|c|c|}
\hline $\begin{array}{l}\text { Effectiveness } \\
\text { theme }\end{array}$ & Typical quotes extracted from observation notes & Site \\
\hline \multirow{4}{*}{$\begin{array}{l}\text { High level of } \\
\text { attention by } \\
\text { participants during } \\
\text { discussions }\end{array}$} & "Some participants sat down to make notes and were very concentrated." & Solsona \\
\hline & $\begin{array}{l}\text { "Very interested and attentive audience when explaining the local forest advising } \\
\text { practices" }\end{array}$ & Freiburg \\
\hline & $\begin{array}{l}\text { "In this group some contradictions became visible what made the discussion more } \\
\text { interesting for the audience." }\end{array}$ & Krakow \\
\hline & „high attention still when near 20 minutes passed $(\ldots)^{\prime \prime}$ & Inverness \\
\hline \multirow{4}{*}{$\begin{array}{l}\text { High quality of the } \\
\text { interaction with } \\
\text { stakeholders }\end{array}$} & $\begin{array}{l}\text { "I think with this process stakeholders became more engaged and enjoy more the } \\
\text { process." }\end{array}$ & Freiburg \\
\hline & „Stakeholders' workshop has very good and deep knowledge." & Helsinki \\
\hline & "Great choice of stakeholders" & Zagreb \\
\hline & „the differing viewpoints of the stakeholders make the discussion vivid." & Inverness \\
\hline \multirow{3}{*}{$\begin{array}{l}\text { High quality of the } \\
\text { information } \\
\text { exchanged }\end{array}$} & "Information of stakeholders was structured." & Helsinki \\
\hline & „Introduction was perfect - led by person who is familiar with situation.“ & Freiburg \\
\hline & $\begin{array}{l}\text { "Questions keep coming and even interesting experiences are revealed. Some } \\
\text { questions include reflections, making questioning more interactive and fostering } \\
\text { dialogue-mode." }\end{array}$ & Zagreb \\
\hline \multirow{6}{*}{$\begin{array}{l}\text { Individual and joint } \\
\text { reflection about } \\
\text { the questions } \\
\text { posed to } \\
\text { stakeholders }\end{array}$} & $\begin{array}{l}\text { "It seems that the interviewees will tell their story regardless of the question } \\
\text { asked." }\end{array}$ & Solsona \\
\hline & „Sometimes questions became too technical." & Helsinki \\
\hline & $\begin{array}{l}\text { "The three wishes question (It was new to me in that context, I found it revealing } \\
\text { and liked it!)“ }\end{array}$ & Freiburg \\
\hline & $\begin{array}{l}\text { "the lady is cheerful and people listen, questions are asked and eagerly answered, } \\
\text { saw people sitting close and writing." }\end{array}$ & Zagreb \\
\hline & $\begin{array}{l}\text { "They expressed their astonishment about the questions the Working Group was } \\
\text { asking them. The first time in the Cost-Action the stakeholder turned the tables and } \\
\text { asked questions back." }\end{array}$ & Krakow \\
\hline & $\begin{array}{l}\text { "The questions were asked "naturally" - each other rise from answer given to the } \\
\text { previous question or leads to nice negotiations - nice conversation not } \\
\text { examination." }\end{array}$ & Inverness \\
\hline
\end{tabular}




\section{Appendix 4}

\section{Researcher's views about the effectiveness of the Travellab in the specific workshops}

\begin{tabular}{|c|c|}
\hline $\begin{array}{l}\text { Solsona (October 2013) - Typical quotes from } \\
\text { researchers }\end{array}$ & $\begin{array}{l}\text { Inverness (April 2016) - Typical quotes from } \\
\text { researchers }\end{array}$ \\
\hline $\begin{array}{l}\text { - "Most useful: Got a picture of how the forest sector } \\
\text { works in this part of Europe, from the small private } \\
\text { owner to policymaker." } \\
\text { - "Very interesting day putting theory into practice. } \\
\text { Great to meet forest owners at the site. Stakeholder } \\
\text { session gave me a lot of new insight in Catalonian } \\
\text { forestry." } \\
\text { - "(...) the perspectives and future trends for PFOA's }{ }^{1} \\
\text { were very well explained and useful for our work } \\
\text { within Working Group." } \\
\text { - "In my opinion Travellab is the most important part } \\
\text { of such a meeting." } \\
\text { - "More structured approach to hold excursions and } \\
\text { meet with stakeholders in workshop helps group to } \\
\text { have joint focus." } \\
\text { - "Travellab is a good technique to getting into real } \\
\text { context." }\end{array}$ & $\begin{array}{l}\text { - "Constructive process: Framing, field visit, } \\
\text { intermediaries." } \\
\text { - "We did something more relevant than } \\
\text { comparing countries." } \\
\text { - "We saw exceptional, model examples in field } \\
\text { trips, - Not complex, messy cases" } \\
\text { - "A distinct improvement compared to other } \\
\text { COST Actions." } \\
\text { - "Collectively, designing and reflecting the } \\
\text { process is valuable." } \\
\text { - "Repeated interaction has value." } \\
\text { - "Good method for us as a group but who is } \\
\text { going to synthesise?" } \\
\text { - "Travellab is not a new "method" rather it is an } \\
\text { "approach" for case study research." } \\
\text { - "People opened up in such a small group." }\end{array}$ \\
\hline
\end{tabular}

\footnotetext{
${ }^{1}$ PFOA's - Private Forest Owners' Associations
} 